\title{
Aliran Kepercayaan Dalam Administrasi Kependudukan
}

\author{
Megamendung Danang Pransefi \\ pransefi@gmail.com \\ Universitas Airlangga
}

Keywords:
Protection of
Believers; Legal
Protection; Human
Rights.

\begin{abstract}
Indonesia is a country with a very plural society, either related ethnicity, language, religion or the beliefs that are diverse among citizens. The 1945 Constitution of the

Republic of Indonesia as the constitutional basis of the State of the Republic of Indonesia guarantees freedom for every citizen to have religion or belief according to what each of them believes. Based on the explanation of Article 1 of Law Number 1 PNPS of 1965, the recognition of majority religion in Indonesian people included Islam, Christianity, Catholicism, Hinduism, Buddhism, and Khong Hu cu. This seems to be a reference that only the six recognised religions in Indonesia, while a long before the arrival of religion in Nusantara (Indonesia), there were already beliefs believed by various communities throughout the archipelago that were actually derived from their ancestors. From these two things it can be seen that there is a gap in the state's treatment, between religion and belief. This gap has been increasingly apparent after the enactment of the article on the Population Administration Law which gave symbol of a dash (-) to followers of religions or beliefs other than the six above religions even though they were still recorded and served in the recording office. Until 2016, the trust groups filled the case to the Constitutional Court to fight for equality of state recognition of their beliefs, due to the Population Administration Law.
\end{abstract} Rights.

Kata Kunci:

Perlindungan

Aliran

Kepercayaan;

Perlindungan

Hukum; Hak

Asasi Manusia.

\begin{abstract}
Abstrak
Indonesia adalah negara dengan pluralitas yang tinggi baik dari suku, bahasa, sampai dengan agama maupun kepercayaan yang dianut tiap-tiap warganya. Undang-Undang Dasar Negara Republik Indonesia Tahun 1945 sebagai dasar konstitusional Negara Republik Indonesia memberikan kebebasan bagi setiap warga negaranya untuk memeluk agama atau kepercayaan sesuai yang diyakini tiap-tiap mereka. Tersirat dari penjelasan pasal 1 Undang-Undang Nomor 1 PNPS Tahun 1965 bahwa agama yang dipeluk oleh masyarakat Indonesia adalah Islam, Kristen, Katolik, Hindu, Buddha, dan Khong hu cu. Hal ini seakan menjadi sebuah acuan bahwa agama yang diakui di Indonesia hanyalah enam agama tersebut, sedangkan jauh sebelum datangnya agama di Indonesia sudah ada kepercayaan-kepercayaan yang diyakini berbagai masyarakat di seluruh penjuru nusantara yang sejatinya turunan dari nenek moyang mereka. Dari dua hal tersebut dapat dilihat adanya kesenjangan akan perlakuan negara terhadap agama dan kepercayaan. Kesenjangan ini semakin tampak setelah adanya pasal Undang-Undang Administrasi Kependudukan yang memberi tanda strip (-) kepada pemeluk agama atau kepercayaan selain enam agama diatas walaupun tetap dicatat dan dilayani di kantor pencatatan. Sampai pada tahun 2016 kelompok penghayat kepercayaan menggugat Undang-Undang Administrasi Kependudukan ke Mahkamah Konstitusi untuk memperjuangkan kesetaraan akan pengakuan negara terhadap kepercayaannya.
\end{abstract}


Megamendung Danang: Aliran Kepercayaan Dalam...

\section{Pendahuluan}

Bangsa Indonesia merupakan bangsa yang plural dalam hal beragama dan/ atau berkeyakinan. Pluralitas yang dimiliki bangsa Indonesia sepanjang sejarah menunjukkan bahwa tradisi toleransi sudah terbangun secara alami di tengahtengah masyarakat terlebih dahulu sebelum hadirnya agama. Oleh karena itu, pengakuan dan toleransi tersebut bukan hanya untuk agama yang berbeda, tetapi juga untuk aliran kepercayaan yang berbeda. Hal ini penting diperhatikan sebagai pengalaman historis bangsa Indonesia yang akan mempengaruhi pola pikir bangsa di masa mendatang. ${ }^{1}$

Suatu bangsa tidak mungkin mengembangkan tradisi baru yang total terpisah dari akar-akar kesejarahannya. Pemikiran demikian pula yang mendasari pentingnya jaminan pengakuan dan perlindungan bagi eksistensi agama dan / atau keyakinan atau aliran kepercayaan di Indonesia. Jaminan pengakuan dan perlindungan tersebut selama ini terkandung dalam Pancasila, Sila Ketuhanan Yang Maha Esa sebagai dasar kuat nilai-nilai yang mencerminkan toleransi terhadap agama dan / atau keyakinan. Nilai-nilai ini selanjutnya dikejawantahkan kembali dalam Konstitusi dalam bentuk hak dan kebebasan beragama dan / atau berkeyakinan dan beribadah menurut agama dan kepercayaan masing-masing sebagaimana tercantum dalam Pasal 29 Undang-Undang Dasar Negara Republik Indonesia Tahun 1945.

Namun kemudian muncul masalah ketika pengakuan terhadap agama dan / atau keyakinan tersebut dibatasi dengan dikeluarkannya Undang-UndangNomor 1.Pn.Ps. Tahun 1965 tentang Pencegahan Penyalahgunaan dan atau Penodaan Agama (UU PNPS No.1 tahun 1965). Dalam penjelasan Pasal 1 UU PNPS No. 1 Tahun 1965 dinyatakan bahwa agama-agama yang dipeluk oleh penduduk Indonesia ialah Islam, Kristen, Katolik, Hindu, Budha dan Kong Hu Cu. Padahal kenyataannya, banyak kepercayaan lokal yang masih eksis di Indonesia

\footnotetext{
1 Airin Liemanto Muhammad Dahlan, ‘PERLINDUNGAN HUKUM ATAS HAK KONSTITUSIONAL PARA PENGANUT AGAMA-AGAMA LOKAL DI INDONESIA' (2017) 10 Arena Hukum <https://arenahukum.ub.ac.id/index.php/arena/article/view/251>.[20-39].
} 
Selama ini banyak diskriminasi lain yang telah dirasakan oleh penghayat kepercayaan akibat perlindungan hukum yang tidak konsisten. Seperti kesulitan dalam membuat akta atau dokumen tertentu bagi anak-anak mereka yang karena perkawinan mereka dengan menggunakan adat kepercayaan mereka tidak diakui oleh Pemerintah. ${ }^{2}$ Kemudian, berbagai permasalahan dari aspek pemenuhan hakhak dasar dan kebijakan publik, yakni banyaknya ketidakcocokan antara identitas agama yang dituliskan di dalam Kartu Keluarga (KK) dan KTP Elektronik. Dalam hal pekerjaan,dibeberapa kasus penganut kepercayaan ini tidak diizinkan berlibur pada hari peribadatan kepercayaan yang dianut. ${ }^{3}$

Selanjutnya apa yang dialami oleh penganut kepercayaan Ugamo Bangso Batak di Medan, Sumatera Utara. Banyak kerugian konstitusional yang dirasakan oleh penganut Ugamo Bangso, misalnya dalam hal mendapatkan pekerjaan dan akses modal usaha dari lembaga keuangan (seperti bank atau koperasi). Pengalaman dalam hal ini salah satunya dialami oleh salah satu pemohon yaitu Arnold Purba ketika anaknya yang bernama Dessy Purba ditolak dari pekerjaan karena dianggap ateis atau kafir akibat tanda strip (-) di kolom agama dalam KTP Elektronik. ${ }^{4}$

Selasa 7 November 2017 Mahkamah Konstitusi menjatuhkan Putusan Nomor 97/PUU-XIV/2016 atas perkara Pengujian Undang-Undang (Judicial Review) Undang-Undang Nomor 23 Tahun 2006 ( UU No.23 Tahun 2006) sebagimana telah diubah dengan Undang-Undang Nomor 24 Tahun 2013 tentang Perubahan atas UU No.23 Tahun 2006 tentang Administrasi Kependudukan (UU No.24 tahun 2013) terhadap UU Negara Republik Indonesia 1945. Perkara ini diajukan oleh beberapa pemohon yang secara keseluruhan merupakan penghayat kepercayaan tertentu di Indonesia. Ruang lingkup pasal yang diuji meliputi, Pasal 61 ayat (1) dan ayat (2) UU No.23 Tahun 2006 dan Pasal 64 ayat (1) dan ayat (5) UU No.24 Tahun 2013. Pasal 61 ayat (1) mengatur tentang sejumlah keterangan yang harus dicantumkan di dalam KK yang berisi beberapa kolom, salah satunya kolom agama. Sementara

\footnotetext{
2 Putusan MK Nomor 97/PUU-XIV/2016.[5-7].

3 ibid.[7].

4 ibid.[9].
} 
Megamendung Danang: Aliran Kepercayaan Dalam...

Pasal 61 ayat (2) mengatur tentang pengosongan kolom agama yang dimaksud alam Pasal 61 ayat (1) bagi Penduduk yang agamanya belum diakui sebagai agama berdasarkan ketentuan perundang-undangan atau bagi penghayat kepercayaan.

Sedangkan Pasal 64 ayat (1) dan (5) UU No.24 Tahun 2013 pada dasarnya mengatur hal yang sama dengan Pasal 61 ayat (1) dan ayat (2) dalam konteks pengurusan KTP Elektronik. Berdasarkan Pasal 64 ayat (5) kolom agama dalam KTP Elektronik bagi Penduduk yang agamanya belum diakui sebagai agama berdasarkan ketentuan perundang-undangan atau bagi penghayat kepercayaan adalah tidak diisi atau dikosongkan.

Hasil akhir dari perjuangan para pemohon dalam perkara tersebut adalah dikabulkannya permohonan Pemohon untuk seluruhnya oleh Majelis Hakim melalui melalui Putusan No.97/PUU-XIV/2016. Dalam putusannya, Majelis Hakim menyatakan bahwa pasal 61 ayat (2) dan pasal 64 ayat (5) UU No.23 Tahun 2006 jo UU No.24 Tahun 2013 bertentangan dengan Undang-Undang Dasar Negara Republik Indonesia dan tidak mempunyai kekuatan hukum mengikat secara bersyarat sepanjang tidak termasuk penganut aliran kepercayaan. ${ }^{5}$

Tidak dapat diragukan bahwa agama memainkan peran yang sangat penting di Indonesia. Memiliki agama sebagai bagian dari keharusan identitas individual menjadi penting dalam proses reproduksi "politik identitas" di Indonesia. Kepemilikan agama bahkan telah menjadi bagian dari "jati diri bangsa" (national identity). Dengan demikian, penting sekali negara melindungi dan menegakkan jaminan kebebasan beragama atau berkeyakinan tanpa diskriminasi bagi setiap warga negara.

Kerangka jaminan kebebasan kehidupan beragama atau berkeyakinan di Indonesia sering diakui cukup kuat. Namun, keindahan kerangka ini belum tentu serta merta indah pula dalam legislasi serta pada peraturan penunjangnya. Seringkali dikeluhkan juga bahwa jaminan kerangka normatif belum menjadi realita yang dapat dinikmati oleh semua warga negara. Banyak sekali warga negara

5 Kodrat Setiawan, 'MK Putuskan Aliran Kepercayaan Masuk Kolom Agama' (Tempo 2017). 
Indonesia yang masih merasa dikekang kebebasannya di dalam memeluk agama atau keyakinannya. Secara garis besar, kerangka normatif jaminan hak kebebasan beragama atau berkeyakinan di Indonesia tercantum dalam UUDNRI 1945, UU No.39/1999 dan instrumen internasional yang telah diratifikasi Indonesia.

UUDNRI 1945 menjamin secara tegas hak kebebasan beragama dan berkeyakinan. Bagian pembukaan menyebut sila pertama dari Pancasila, “Ketuhanan Yang Maha Esa”. Dengan adanya sila ini, Indonesia digambarkan sebagai negara yang bukan sekuler melainkan sebagai negara yang mempunyai ciri religius. Sedangkan Bab XA tentang hak asasi manusia mengatur hak kebebasan beragama dan berkeyakinan. Pasal 28E ayat 1 dan 2 berbunyi setiap orang bebas memeluk agama dan beribadat menurut agamanya, memilih pendidikan dan pengajaran, memilih pekerjaan, memilih kewarganegaraan, memilih tempat tinggal di wilayah negara dan meninggalkannya, serta berhak kembali, setiap orang berhak atas kebebasan meyakini kepercayaan, menyatakan pikiran dan sikap, sesuai dengan hati nuraninya.

Pada prinsipnya hak ini tidak dapat dikurangi dalam keadaan apa pun. Namun demikian, setiap orang wajib tunduk kepada pembatasan yang ditetapkan dengan undang-undang. Pembatasan ini dimaksudkan semata-mata untuk menjamin pengakuan serta penghormatan atas hak dan kebebasan orang lain dan untuk memenuhi tuntutan yang adil sesuai dengan pertimbangan moral, nilainilai agama, keamanan, dan ketertiban umum dalam suatu masyarakat demokratis dimana sesuai dengan pasal 28J (2).

Dalam bab tersendiri (Bab XI Agama), pasal 29 menyatakan negara menjamin kemerdekaan tiap-tiap penduduk untuk memeluk agamanya masing-masing dan untuk beribadat menurut agamanya dan kepercayaan itu. Dalam hal ini, negara (pemerintah) adalah institusi yang pertama-tama berkewajiban untuk menjamin kebebasan beragama dan berkeyakinan, dan segala sesuatu yang menjadi turunannya, seperti pengakuan hak-hak sipil lainnya. ${ }^{6}$ Jaminan hak kebebasan

6 UUDNRI 1945 Ps.28I (4). 
Megamendung Danang: Aliran Kepercayaan Dalam...

beragama dan berkeyakinan ini ditindaklanjuti dengan penegasan bahwa setiap orang berhak bebas dari perlakuan yang bersifat diskriminatif atas dasar apa pun dan berhak mendapatkan perlindungan terhadap perlakuan yang bersifat diskriminatif itu. ${ }^{7}$

Undang-undang Nomor 39 Tahun 1999 tentang Hak Asasi Manusia (UU No.39/1999) dapat dikatakan merupakan payung dari semua regulasi yang mengatur tentang hak asasi manusia di Indonesia. Selain mengatur tentang berbagai macam hak dasar warga negara, UU No.39/1999 juga menegaskan tentang kewajiban dan tanggung jawab pemerintah. Sama halnya dengan UUDNRI 1945, UU No.39/1999 juga menegaskan bahwa negara bertanggungjawab atas dijaminnya kebebasan beragama dan berkeyakinan.

Pasal 8 menegaskan bahwa perlindungan, pemajuan, penegakan dan pemenuhan hak asasi manusia menjadi tanggung jawab negara, terutama pemerintah. Pasal 71 melanjutkan bahwa pemerintah wajib dan bertanggung jawab menghormati, melindungi, menegakkan dan memajukan hak asasi manusia yang diatur dalam UU No. 39/1999, peraturan perundang-undangan lain dan hukum internasional tentang hak asasi manusia yang diterima oleh negara Republik Indonesia. Namun demikian, UU No.39/1999 memiliki kelemahan karena hanya memungkinkan seseorang atau sekelompok orang untuk mengajukan laporan pengaduan lisan atau tertulis pada Komisi Nasional Hak Asasi Manusia (Komnas HAM) apabila memiliki alasan kuat bahwa hak asasinya telah dilanggar, sesuai pasal 90(1). Disamping itu, UU No.39/1999 hanya memuat norma tanpa sanksi, sehingga implementasi jaminan perlindungan HAM masih terkesan abstrak.

Disamping UUDNRI 1945 dan UU No.39/1999, tuntutan untuk menjamin kebebasan beragama atau berkeyakinan juga tertuang dalam Konvenan Internasional tentang Hak Sipil dan Politik. Indonesia sudah meratifikasi Kovenan tersebut melalui Undang-Undang No. 12 Tahun 2005 tentang Pengesahan International Convenant on Civil and Political Rights (Kovenan Internasional tentang

7 ibid.[28I (2)]. 
Hak-hak Sipil dan Politik). Indonesia mengesahkan Kovenan ini karena pada dasarnya tidak bertentangan dengan Pancasila dan UUDNRI 1945 dan dianggap sesuai dengan sifat Negara Republik Indonesia sebagai negara hukum yang menjujung tinggi harkat dan martabat manusia serta keinginan bangsa Indonesia untuk secara terus menerus memajukan dan melindungi hak asasi manusia dalam kehidupan berbangsa dan bernegara.

Indonesia telah meratifikasi Konvensi Internasional tentang Penghapusan Segala BentukDiskriminasi Rasial pada tahun 1999 melalui Undang-undang Nomor 29 Tahun 1999 tentang Pengesahan International Convention on the Elimination of All Forms of Racial Discrimination 1965 (Konvensi Internasional tentang Penghapusan Segala Bentuk Diskriminasi Rasial 1965) dengan alasan serupa.

Dengan meratifikasi Kovenan dan Konvensi tersebut, Indonesia sebagai negara pihak terikat secara hukum dan harus menghormati, melindungi dan memenuhi hak-hak yang terkandung di dalamnya. Di samping itu, hukum Indonesia juga menegaskan bahwa ketentuan hukum internasional yang telah diterima Negara Republik Indonesia yang menyangkut HAM menjadi hukum nasional, ${ }^{8}$ dan bahwa pemerintah wajib dan bertanggung jawab menghormati, melindungi, menegakkan dan memajukan hak asasi manusia yang diatur dalam hukum internasional tentang HAM yang diterima oleh Negara Republik Indonesia. ${ }^{9}$

Kovenan Internasional tentang Hak Sipil dan Politik menetapkan hak setiap orang atas kebebasan berpikir, berhati nurani dan beragama, dan kebebasan untuk menjalankan agama atau keyakinan dalam kegiatan ibadah, penataan, pengamalan, dan pengajaran. ${ }^{10}$ Kewajiban negara untuk melarang segala tindakan yang menganjurkan diskriminasi, permusuhan atau kekerasan; ${ }^{11}$ dan hak kelompok minoritas untuk menjalankan dan mengamalkan agamanya sendiri. ${ }^{12}$ Hak kebebasan beragama atau berkeyakinan sudah lama dikaji dan dibicarakan

\footnotetext{
Undang-Undang Nomor 39 Tahun 1999 tentang Hak Asasi Manusia.[7(2)].

ibid.[71].

${ }^{10}$ Kovenan Internasional Hak-Hak Sipil dan Politik.[18].

11 ibid.[20(2)].

12 ibid.[21].
} 
di tingkat internasional, dan ketentuan hukumnya pun sudah mendetail. Perlu dicatat di sini bahwa walaupun hukum internasional menggunakan istilah "kebebasan beragama atau berkeyakinan", dan bukan "kebebasan beragama dan berkeyakinan", hal ini tidak berarti bahwa hak ini hanya melindungi salah satu dari agama dan keyakinan. Hak ini meliputi hak kebebasan berpikir, berhati nurani dan beragama (termasuk kebebasan menghayati keyakinan).

Hak ini memiliki sifat internal dan eksternal. Sifat internal dari hak ini diartikan bahwa setiap orang berhak atas kebebasan berpikir, berhati nurani dan beragama. Hak ini mencakup kebebasan untuk setiap orang menganut, menetapkan, mempertahankan atau pindah agama atau kepercayaan. Sedangkan sifat eksternal dari hak ini berarti bahwa setiap orang mempunyai kebebasan, baik diri sendiri atau bersama-sama dengan orang lain, di tempat umum atau tertutup, untuk menjalankan agama atau keyakinannya dalam kegiatan pengajaran, pengamalan, ibadah dan penataan. ${ }^{13}$

Beradasarkan sifat internal dari hak ini, maka sesungguhnya tidak seorang pun dapat dipaksakan sehingga terganggu kebebasannya untuk menganut atau menerapkan agama atau keyakinan sesuai dengan pilihannya. ${ }^{14}$ Dalam hal ini negara berkewajiban untuk menghormati dan menjamin hak dan kebebasan beragama atau berkeyakinan bagi semua orang yang berada dalam wilayahnya dan tunduk pada wilayah hukumnya, tanpa pembedaan apa pun seperti ras, warna kulit, jenis kelamin, bahasa, agama, politik atau pendapat lain, kebangsaan atau asal-usul lainnya, kekayaan, kelahiran atau status lainnya. ${ }^{15}$

Hak ini tidak boleh dikurangi dalam keadaan apapun., bahkan dalam keadaan darurat. ${ }^{16}$ Namun kebebasan eksternal dapat dibatasi oleh ketentuan hukum sepanjang diperlukan untuk melindungi keamanan, ketertiban, kesehatan, moral masyarakat, atau hak-hak mendasar orang lain. ${ }^{17}$

\footnotetext{
${ }^{13}$ Konvenan Internasional tentang Hak-Hak Sipil dan Politik.[18(1)]

14 ibid, pasal [18(2)].

15 ibid, pasal [2(1)].

16 ibid, pasal [4(2)].

17 ibid, pasal [18(3)].
} 
Sesuai dengan Konvensi Internasional tentang Penghapusan Segala Bentuk Diskriminasi Rasial, negara pihak berjanji untuk melarang dan menghapuskan segala bentuk diskriminasi rasial dan menjamin hak setiap orang, tanpa membedakan ras, warna kulit, asal usul etnik atau kebangsaan, untuk mendapatkan kesederajatan di hadapan hukum, khususnya dalam menikmati hak atas kebebasan berpikir, berkeyakinan dan beragama. Pasal 5 huruf (d) angka romawi (vii). Dalam Konvensi ini “diskriminasi rasial” berarti setiap pembedaan, pengucilan, pembatasan atau pilihan berdasarkan ras, warna kulit, keturunan atau asal usul etnik atau kebangsaan, yang bertujuan atau berakibat mencabut atau mengurangi pengakuan, perolehan pelaksanaan hak asasi manusia dan kebebasan mendasar, dalam suatu kesederajatan, di bidang politik, ekonomi, sosial, budaya atau dan kebebasan mendasar, dalam suatu kesederajatan, di bidang politik, ekonomi, sosial, budaya atau bidang-bidang kehidupan kemasyarakatan lainnya: pasal1(1).

Dalam rangka melaksanakan Konvensi Internasional tentang penghapusan Segala Bentuk Diskriminasi, maka telah diundangkan Undang-undang Nomor 40 Tahun 2008 tentang Penghapusan Diskriminasi Ras dan Etnis yang berlaku pada akhir tahun 2008. Namun, undang-undang ini memiliki kelemahan bahwa diskriminasi atas dasar agama tidak merupakan tindakan ras dan etnis, serta hak setiap warga negara untuk memperoleh perlakuan yang sama dalam hal mendapatkan hak-hak sipil, politik, ekonomi, sosial, dan budaya tidak meliputi hak kebebasan beragama atau berkeyakinan. Akan tetapi, diskriminasi atas dasar "kepercayaan" dilarang, dan hak atas budaya dilindungi.

Dalam pasal 1 UU No.40 Tahun 2008, diskriminasi ras dan etnis adalah segala bentuk pembedaan, pengecualian, pembatasan atau pemilihan berdasarkan pada ras dan etnis yang mengakibatkan pencabutan atau pengurangan pengakuan, perolehan atau pelaksanaan hak asasi manusia dan kebebasan dasar dalam suatu kesetaraan di bidang sipil, politik, ekonomi, sosial dan budaya. Ras adalah golongan bangsa berdasarkan ciri-ciri fisik dan garis keturunan. Etnis adalah penggolongan manusia berdasarkan kepercayaan, nilai , kebiasaan, adat istiadat, norma Bahasa, sejarah, geografis dan hubungan kekerabatan. Tindakan 
diskriminasi ras dan etnis adalah perbuatan yang berkenaan dengan segala bentuk pembedaan, pengecualian, pembatasan, atau pemilihan berdasarkan pada ras dan etnis, yang mengakibatkan pencabutan atau pengurangan pengakuan, perolehan, atau pelaksanaan hak asasi manusia dan kebebasan dasar dalam suatu kesetaraan di bidang sipil, politik, ekonomi, sosial dan budaya.

Pasal 9 kovenan hak sipol Setiap warganegara berhak memperoleh perlakuan yang sama untuk mendapatkan hak-hak sipil, politik, ekonomi sosial dan budaya sesuai dengan ketentuan peraturan perundang-undangan, tanpa pembedaan ras dan etnis.

Berbagai pengaturan di atas membenarkan pendapat bahwa kerangka jaminan kebebasan kehidupan beragama atau berkeyakinan di Indonesia cukup kuat. Namun, sangat penting diingat bahwa negara harus mengakui keterkaitan antara jaminan ini dengan kewajibannya untuk memenuhi hak tersebut. Keterkaitan ini mewajibkan negara, terutama pemerintah, untuk melakukan serangkaian tindakan yang menjamin implementasi yang efektif dan sesuai dengan HAM. Keindahan kerangka normatif yang diuraikan di atas harus indah pula baik dalam legislasi serta dalam peraturan penunjangnya, maupun kebijakan dan keputusan administratif pemerintah.

Kewajiban ini diakui pemerintah dalam Rencana Aksi Nasional Hak Asasi Manusiatahun2004-2009yangmenjelaskanbahwapembentukanperaturanperundangundangan di tingkat nasional yang sesuai dengan Kewenangan Internasional tentang Hak-hak Sipil dan Politik akan mempertegas diakuinya kebebasan untuk memeluk agama dan keyakinan sebagai suatu hak yang fundamental.

UU No. 1/PNPS/1965 tentang Pencegahan Penyalahgunaan dan / atau Penodaaan Agama (UU No.1/PNPS/1965) menyebabkan agama-agama yang dipeluk oleh penduduk Indonesia hanya Islam, Kristen, Katolik, Hindu, Budha dan Khong $\mathrm{Hu} \mathrm{Cu}$ (Confucius). Undang-undang ini menegaskaskan bahwa agama-agama lainnya, seperti Yahudi, Zarasustrian, Shinto, Taoisme tidak dilarang di Indonesia, namun undang-undang ini secara tidak langsung hanya mengakui secara resmi enam agama saja. Hal ini dapat dilihat dalam undang- 
undang no.23 tahun 2006 yang menggunakan istilah "agama yang belum diakui". UU No.1/PNPS/1965 ini menyebutkan larangan melakukan penafsiran atau kegiatan yang menyimpang dari pokok-pokok ajaran agama. Hal ini berarti bahwa undang-undang tersebut menandakan bila persepsi negara tentang agama masih didominasi oleh pemahaman arus utama yang menyatakan bahwa suatu agama harus memiliki Tuhan, nabi dan kitab suci.

Dengan demikian dapat disimpulkan bahwa UU No.1/PNPS/1965 tidak mengakui "keyakinan" dan mengartikan "agama" sempit. Kenyataan ini bertentangan dengan kewajiban Indonesia untuk menafsirkan istilah "agama" dan "keyakinan" secara luas.

Korban dari UU No.1/PNPS/1965 serta didirikannya lembaga-lembaga agama resmi adalah penganut agama atau keyakinan di luar enam agama tersebut. Belum lagi orang yang tidak beragama. Diawal Orde Baru orang diwajibkan beragama dan kalau tidak, maka orang akan dengan mudah dituduh PKI (Partai Komunis Indonesia) Maka segera setelah 1965, banyak sekali orang yang "masuk agama resmi".

Bagi pemeluk agama atau keyakinan di luar agama-agama yang dipeluk oleh penduduk Indonesia misalnya komunitas masyarakat adat, mereka sering dituding sebagai pemeluk agama sempalan harus kembali ke agama induknya, sebagai pengganggu ketertiban umum, penoda agama resmi, kelompok yang belum beradab dan sebagainya. ${ }^{18}$ Misalnya para penganut Sunda Wiwitan, yang dipeluk oleh masyarakat Sunda di Kanekes, Lebak, banten, diarahkan kembali ke agama Hindu. Bahkan aliran agama kepercayaan dipandang sebagai budaya, bukan agama. Komunitas masyarakat adat adalah sekelompok masyarakat yang hidup berdasarkan asal usul leluhur dalam suatu wilayah geografis tertentu, memiliki system nilai dan sosial budaya yang khas, berdaulat atas tanah dan kekayaan alamnya serta mengatur dan mengurus keberlanjutan kehidupannya dengan hukum dan kelembagaan adat. ${ }^{19}$

\footnotetext{
18 Tore Lindholm, [et. al], Kebebasan Beragama Atau Berkeyakinan Seberapa Jauh (Kanisius 2010). [691]. 
Megamendung Danang: Aliran Kepercayaan Dalam...

Negara Indonesia tidak mengakui keagamaan kepercayaan lokal dan sekte-sekte agama baru, dan kesulitan yang muncul karena keragaman ini hanya dihindari dengan cara memaksa orang untuk percaya kepada satu Tuhan. Secara administratif, penduduk yang tidak memeluk enam agama resmi tidak berada dalam pengawasan dan pengurusan Departemen Agama, mereka berada dalam pengawasan Departemen Pendidikan dan Kebudayaan. Kementerian Pendidikan dan Kebudayaan (sekarang Kementrian Pendidikan Nasional) mengawasi kurang lebih 246 organisasi agama lokal. Jumlah organisasi terus berubah, beberapa dari mereka membubarkan diri, sebagian lain dilarang pemerintah, misalnya agama Karuhun yang pelarangannya ditetapkan oleh Kejaksaan Tinggi Jawa Barat pada 1982. Beberapa agama lokal atau sekte baru tumbuh menjadi asosiasi yang cukup modern, misalnya penganut agama Karuhun yang mengorganisasi diri dalam PAKCU, tapi sebagian lain bahkan tidak diorganisasi oleh Kemetrian Pendidikan dan Kebudayaan dan tidak memiliki perwakilan apapun. ${ }^{20}$

Sifat internal dari hak kebebasan beragama atau berkeyakinan (yaitu hak setiap warga negara untuk menganut atau menetapkan agama atau keyakinannya atas pilihan sendiri) tidak boleh dibatasi karena merupakan persoalan individu dan bukan persoalan negara. Kebebasan ini dilindungi tanpa syarat apapun. ${ }^{21}$ Negara tidak boleh menetapkan mana ajaran agama yang harus dan tidak harus dianut oleh warga negara. Setiap warga negara mesti mendapatkan hak dan kebebasannya dalam menentukan pilihan agamanya.

Pendefinisian agama menyingkirkan kelompok di luar enam agama tersebut dengan segala konsekuensi peniadaan hak-hak sipil dan politik mereka. Padahal menurut Agus Salim, salah satu tokoh penting "bapak pendiri bangsa Indonesia", Pancasila menjamin setiap warga negara memeluk agama apa pun, bahkan juga menjamin setiap warga negara untuk memilih tidak beragama sekalipun.

\footnotetext{
${ }^{20}$ Abdullahi Ahmed An-Na'im, Islam Dan Negara Sekular : Menegosiasikan Masa Depan Syariah (Mizan 2007).[405].

${ }^{21}$ UUDNRI 1945, [28].
} 
Hak asasi manusia tidak mengenal batasan. Lebih dari lima puluh tahun setelah adopsi Deklarasi Universal Hak Asasi Manusia, kita baru saja mulai memahami dampak sesungguhnya dari pengakuan universalitas hak asasi manusia adalah hak asasi untuk semua. Hal ini berarti bahwa perjuangan untuk kebebasan beragama atau berkeyakinan bagi setiap individu adalah perjuangan dari setiap pemerintah dan tanggung jawab dari setiap pemerintah. Agama adalah sebuah kekuatan yang luar biasa. Kebebasan beragama atau berkeyakinan termasuk juga kebebasan, baik sendiri maupun di dalam komunitas dengan orang lain, diruang publik atau privat, untuk mempraktekkan agama atau keyakinan seseorang, baik melalui pemujaan, kepatuhan terhadap kebiasaan-kebiasaan ataupun ajaran keagamaan. Kebebasan beragama atau berkeyakinan juga mencakup baik untuk tidak memiliki agama atau keyakinan, dan untuk mengubah agama seseorang. ${ }^{22}$

Pada bagian pertimbangan hukum Hakim dalam Putusan MK Nomor 97/PUU-XIV/2016, Hakim berpandangan bahwa pada hakikatnya hak untuk menganut agama atau kepercayaan terhadap Tuhan Yang Maha Esa merupakan hak konstitusional warga negara dan bukan pemberian negara. Dalam prinsip negara hukum demokratis, peran negara adalah berkewajiban untuk melindungi yang juga berarti menghormati dan menjamin pemenuhan hak-hak tersebut. Hak menganut agama atau kepercayaan adalah bagian dari hak asasi manusia kelompok hak-hak sipil dan politik. Hak asasi ini bersumber dari konsepsi hakhak alamiah (natural rights). Sebagai bagian dari natural rights, maka hak ini melekat pada setiap orang karena kodratnya sebagai manusia, dan sekali lagi bukan pemberian negara. ${ }^{23}$

Secara Konstitusional kebebasan beragama atau berkeyakinan juga telah dijamin dalam Pasal 28E ayat (1) dan (2), dan Pasal 29 ayat (2) UUDNRI 1945. Ketentuan dalam pasal-pasal tersebut tersebut memberikan jaminan kebebasan kepada setiap warga negara untuk memeluk agama dan beribadah sesuai dengan keyakinan masing-masing, disertai dengan kewajiban negara melindungi setiap

\footnotetext{
${ }^{22}$ Tore Lindholm, [et. (n 18).).[10].

${ }^{23}$ Putusan MK Nomor 97/PUU-XIV/2016 [138-139].
} 
Megamendung Danang: Aliran Kepercayaan Dalam...

warga negara untuk beribadah sesuai dengan keyakinan masing-masing, tanpa terkecuali penghayat kepercayaan.

Sebagai hak kodrati yang melekat pada diri setiap manusia sebagai mahluk Tuhan Yang maha Esa, seharusnya kebebasan beragama merupakan hak asasi manusia yang tidak dapat dikurangi dalam keadaan bagaimanapun. Namun di Indonesia dipahami bahwa pembatasan hak asasi manusia dimungkinkan asalkan dilakukan hanya dengan undang-undang tertentu dalam beberapa kasus seringkali memunculkan ketidakpastian hukum dan justru menimbulkan perlakuan yang diskriminatif. Seperti halnya ketentuan kolom agama di dalam UU Administrasi Kependudukan, baik UU No.23 Tahun 2006 maupun UU No.24 Tahun 2013, dimana pada praktek aliran kepercayaan atau penghayat kepercayaan legitimasinya tidak dijamin karena tidak dapat mengisi kolom agama dalam KK maupun KTP Elektronik.

Padahal, jika merujuk pada Pasal 58 ayat (2) huruf H UU No.23 Tahun 2006 diatur mengenai data dan dokumen pendudukan yang terdiri dari data perseorangan salah satunya "agama/kepercayaan". Sehingga seharusnya ketentuan di dalam pasal lainnya, khususnya Pasal 61 ayat (1) dan (2) jo Pasal 64 ayat (1) dan (5) UU Administrasi Kependudukan secara konsisten juga memuat frasa "agama/kepercayaan" dan bukan hanya "agama" saja. Pada akhirnya frasa "agama" ini hanya merujuk pada 6 (enam) agama yang diakui di Indonesia sebagaimana disebutkan dalam UU PNPS No.1 tahun 1965.

Dalam pertimbangan hakim Putusan Mahkamah Konstitusi Nomor 97 Tahun 2016 ini bahwa dengan tidak dianutnya pengertian terminologi "agama" dalam pasal 61 ayat 1 dan pasal 64 ayat 1 UU Administrasi Kependudukan termasuk kepercayaan. Maka dengan sendirinya norma undang-undang memberikan kepastian bahwa mereka bukan penganut agama yang diakui sesuai dengan peraturan perundang-undangan. Hal ini sekaligus tidak memungkinkan bagi mereka menikmati perlakuan yang sama dihadapan hukum secara adil. Sebab secara konseptual dalam konstruksi UU administrasi kependudukan mereka tidak termasuk dalam pengertian agama. Pengaturan tersebut telah memperlakukan 
secara berbeda terhadap hal yang sama yakni terhadap warga negara penghayat kepercayaan dan warga negara penganut agama. Hal tersebut bertentangan dengan pasal 28J UUDNRI Tahun 1945. Maka Mahkamah Konstitusi berpendapat pembatasan atas dasar keyakinan yang berimplikasi pada timbulnya perlakuan berbeda antar warga negara yang merupakan tindakan diskriminatif.

\section{Kesimpulan}

Perlindungan kebebasan beragama sejatinya mendahului perlindungan hak-hak lain. Agama merupakan salah satu urusan pemerintah pusat. Secara garis besar, kerangka normatif jaminan hak kebebasan beragama atau berkeyakinan di Indonesia tercantum dalam UUDNRI 1945, UU No.39/1999 dan instrumen internasional yang telah diratifikasi Indonesia. Hak kebebasan beragama dan berkeyakinan di Indonesia belum secara merata terlindungi oleh hukum di Indonesia. Sebelum adanya putusan MK No.97 Tahun 2016 hak masyarakat penghayat kepercayaan terdiskriminasi oleh UU Adminduk dalam hal pencatatan di kartu tanda penduduk yakni dengan ditulis strip (-) meski tetap diakui dan dilayani dalam urusan pemerintahan. Namun pada prakteknya banyak penghayat yang mengalami kesulitan dalam berkehidupan karena adanya pasal tersebut seperti susah mencari pekerjaan, pembuatan akta kelahiran dan sebagainya. Adapun masyarakat penghayat kepercayaan ini apabila tidak ingin mengalami kesulitan tersebut harus membohongi dirinya dengan mencantumkan agama lain. Hal tersebut sangat kontradiktif dengan kebebasan beragama yang sejatinya diusung dalam UUDNRI 1945.

Seluruh warga negara bebas memeluk agama dan kepercayaan masingmasing dengan saling menghormati hak beragama dan berkeyakinan orang lain dengan penuh toleransi. Dari pernyataan Soekarno tersebut bukan berarti Indonesia adalah negara agama, entah negara Islam negara Kristen negara Hindu negara Budha dan lainnya akan tetapi negara Indonesia adalah negara yang berketuhanan. Menurut Tore Lindholm, kebebasan beragama juga mencakup baik untuk tidak memiliki agama atau keyakinan (ateis). Oleh karena itu ateis 
Megamendung Danang: Aliran Kepercayaan Dalam...

termasuk salah satu bentuk kebebasan berkeyakinan, yang berarti negara wajib melindungi hak tersebut. Hal ini diperkuat oleh ratio decidendi dalam Putusan Mahkamah Konstitusi No.97 Tahun 2016 yang bertujuan untuk menghindari adanya diskriminasi antar warga negara.

\section{Daftar Bacaan}

\section{Buku}

Tore Lindholm, [et., al]., Kebebasan Beragama Atau Berkeyakinan Seberapa Jauh (Kanisius 2010).

Abdullahi Ahmed An-Na'im, Islam dan Negara Sekular : Menegosiasikan Masa Depan Syariah (Mizan 2007).

\section{Jurnal}

Muhammad Dahlan 'Airin Liemanto, Perlindungan Hukum Atas Hak Konstitusional Para Penganut Agama-Agama Lokal Di Indonesia',(2017) ARENA HUKUM.

\section{Laman}

Kodrat Setiawan, 'MK Putuskan Aliran Kepercayaan Masuk Kolom Agama',(Tempo, 2017) <https://nasional.tempo.co/read/1031506/mkputuskan-aliran-kepercayaan-masuk-kolom-agama-ktp/full\&view=ok> diakases 10 Oktober 2018.

\section{Perundang-undangan}

Undang-Undang Dasar Negara Republik Indonesia Tahun 1945.

Undang-Undang Nomor 1/PNPS/Tahun 1965 tentang Pencegahan Penyalahgunaan dan/atau Penodaan Agama, Lembar Negara Republik Indonesia Nomor 3 Tahun 1965, Tambahan Lembar Negara Republik Indonesia nomor 2726.

Undang-Undang Nomor 29 Tahun 1999 Tentang Pengesahan Convention On The Elimination Of All Forms Of Racial Discrimination 1965 (Konvensi Internasional Tentang Penghapusan Segala Jenis Bentuk Diskriminasi Rasial 1965), Lembaran Negara Republik Indonesia Tahun 1999 Nomor 83.

Undang-Undang Nomor 39 Tahun 1999 Tentang Hak Asasi Manusia, Lembar 
Negara Republik Indonesia Tahun 1999 Nomor 165.

Undang-Undang Nomor 12 Tahun 2005 Tentang Pengesahan Covenant On Civil And Political Rights (Kovenan Internasional Tentang Hak-Hak Sipil Dan Politik), Lembaran Negara Republik Indonesia Tahun 2005 Nomor 119.

Undang-Undang Nomor 23 Tahun 2006 Tentang Administrasi Kependudukan, Lembaran Negara Republik Indonesia Tahun 2006 Nomor 124.

Undang-Undang Nomor 40 Tahun 2008 Tentang Penghapusan Diskrimnasi Ras Dan Etnis, Lembaran Negara Republik Indonesia Tahun 2008 Nomor 170.

Undang-Undang Nomor 24 Tahun 2013 Tentang Perubahan Atas Undang-Undang Nomor 23 Tahun 2006 Tentang Administrasi Kependudukan, Lembaran Negara Republik Indonesia Tahun 2013 Nomor 232.

How to cite: Megamendung Danang Pransefi, 'Aliran Kepercayaan Dalam Administrasi Kependudukan' (2021) Vol. 4 No. 1 Media Iuris. 
--Halaman ini sengaja dibiarkan kosong-- 